A RCHIWA, BIBLIOTEKI

I MUZEA KOŚCIELNE 109 (2018)

https://doi.org/10.31743/abmk.2018.109.11

KRZYSZTOF KACZMAREK* - POZNAŃ

\title{
KONWENT DOMINIKANÓW W BRZEGU W XIV-XVI WIEKU ${ }^{1}$
}

$*$

Dzieje dominikanów w Brzegu pozostawały jak dotąd w głębokim cieniu, jaki na wszystkie właściwie klasztory ufundowane na terenie Śląska rzucał największy i najważniejszy z tych domów, to znaczy wrocławski klasztor pod wezwaniem św. Wojciecha ${ }^{2}$. Klasztor w Brzegu, założony dopiero w połowie XIV w. i działający przez zaledwie dwa stulecia, przyciągał znacznie mniejszą uwagę historyków, zarówno niemieckich jak i polskich. Owszem, fundacja brzeska jest wzmiankowana praktycznie we wszystkich kompendiach kościelnych dziejów Śląska, ale podawane $\mathrm{w}$ tych pracach informacje praktycznie nie wychodzą poza kwestie związane $\mathrm{z}$ fundacją tego domu zakonnego, a potem jego szybką (w dobie reformacji) kasatą ${ }^{3}$ Zapewne właśnie z uwagi na ów szybki upadek brzeskiej fundacji, a następnie rozbiórkę podominikańskich obiektów klasztornych jej działanie zbył

* Krzysztof Kaczmarek - dr hab. historii, prof. UAM; pracownik Zakładu Historii Średniowiecznej Uniwersytetu Adama Mickiewicza w Poznaniu; e-mail: krzymosina@op.pl

${ }^{1}$ Praca powstała w ramach projektu badawczego $\mathrm{nr}$ 2014/13/B/HS3/04911 (Nekrolog klasztoru dominikanów w Brzegu), finansowanego przez Narodowe Centrum Nauki.

${ }^{2} \mathrm{Na}$ jego temat zob. głównie C. Blasel, Geschichte von Kirche und Kloster St. Adalbert zu Breslau, Breslau 1912; z nowszych prac por. J. Kłoczowski, Dominikanie polscy na Śląsku w XIII-XIV wieku, Lublin 1956; tenże, Raz jeszcze o poczatkach polskich dominikanów. Klasztor wroctawski wśród pierwszych konwentów prowincji polskiej, w: Błogosławiony Czesław - patron Wroctawia, t. 1. Średniowiecze i czasy nowożytne, red. M. Derwich, Wrocław-Warszawa 2006, s. 27-29; S. Szczygieł, Początki dominikanów we Wrocławiu, w: Błogosławiony Czesław - patron Wrocławia, t. 1. Średniowiecze i czasy nowożytne, red. M. Derwich, Wrocław-Warszawa 2006, s. 31-41; K. Kaczmarek, Konwent dominikanów wrocławskich w późnym średniowieczu, Poznań-Wrocław 2008; przegląd najnowszych badań nad historią dominikanów śląskich dał ostatnio J. Zouhar, Dějiny a kultura slezských dominikánů v nové historiografii, „Český časopis historický”, 112 (2014) nr 2, s. 287-294.

${ }^{3} \mathrm{~Np}$. J. Heyne, Dokumentirte Geschichte des Bisthums und Hochstiftes Beslau, 1. Bd, Breslau 1860, s. 893-896; K. Dola, Dzieje Kościoła na Śląsku, cz. 1. Średniowiecze, Opole 1996, s. 85. 
milczeniem w swym opisie Brzegu J. Weigel ${ }^{4}$. Niewiele do powiedzenia na temat dominikanów miał także K. Schönwälder, który swe zainteresowania klasztorem ograniczył do podania daty jego fundacji przez księcia Bolesława III i poświęcenia kościoła pod wezwaniem Św. Krzyża przez biskupa Nankera ${ }^{5}$. Równie pobieżne uwagi na temat fundacji w Brzegu zamieścił też w swych dziejach miasta i księstwa brzeskiego H. Schoenborn ${ }^{6}$. Skąpe informacje o klasztorze Braci Kaznodziejów w Brzegu zamieścili również w swych pracach autorzy dziejów protestanckich i katolickich świątyń w tym mieście; wiadomości te ograniczają się zwykle do stwierdzenia samego faktu obecności zakonników na terenie Brzegu i nie da się na ich podstawie nic powiedzieć na temat roli, jaką konwent odgrywał w religijnym życiu miasta i jego okolic ${ }^{7}$. Niewiele do powiedzenia o zakonnikach dominikańskich i ich związkach z brzeskimi mieszczanami mieli też autorzy, podejmujący problematykę gospodarczych dziejów miasta w okresie średniowiecza - skromne, oparte jednak o dokumentową podstawę, informacje na temat związków braci z miejscowymi rzemieślnikami odnajdujemy na kartach opracowania dziejów cechu brzeskich krawców ${ }^{8}$.

Na wyższy poziom wprowadził dyskusję nad dziejami dominikanów w Brzegu A. Schaube. Autor ten nie oświetlił co prawda całej historii klasztoru, ale jako pierwszy poddał gruntownej analizie jego dokument fundacyjny i odtworzył okoliczności zainstalowania zakonników w mieście; A. Schaube podał też informację ważną z punktu widzenia prozopografii konwentu - imię pierwszego przeora klasztoru w Brzegu, którym był brat Szymon, wzmiankowany w źródłach pod rokiem $1342^{9}$. W latach II wojny światowej nie prowadzono znaczących badań nad historią brzeskich dominikanów. Do tematu powrócił dopiero po jej zakończeniu K. Eisert, który w 1960 r. opublikował jedyny jak dotąd kompleksowy zarys dziejów klasztoru obejmujący lata 1336-1545. W przeciwieństwie do swych (i taknielicznych) poprzedników skupionych na analizie samego aktu fundacyjnego K. Eisert odtworzył na podstawie zachowanych dokumentów gospodarcze podstawy funkcjonowania klasztoru, a także wprowadził do swych rozważań zupełnie nowe wątki związane z pochodzeniem zakonników tworzących brzeski konwent i jego składem osobowym. Autor sądził, że obsada klasztoru była skromna;

${ }^{4}$ J.A.W. Weigel, Geographische, naturhistorische und technologische Bechreibung des souverainen Herzogthums Schlesien, 3. Th. Die Fürstenthümer Münsterberg und Brieg, Berlin 1801, s. 136-142.

${ }^{5}$ K.F. Schönwälder, Die Piasten zum Briege oder Geschichte der Stadt und des Fürstenthums Brieg. 1. Bd. Von den ältesten Nachrichten bis zum Jahre 1521, Brieg 1855, s. 146-147.

${ }^{6}$ H. Schoenborn, Geschichte der Stadt und des Fürstentums Brieg. Ein Ausschnitt aus der Geschichte Schlesiens, Brieg 1907, s. 52-53.

${ }^{7}$ Zob. Festschirift zur 400 Jahr-feier der Brieger Reformation, hrsg. von W. Gunkel, Brieg 1924, s. 19; F. Scholz, Einführung der Reformation im Fürstentum Brieg, Brieg 1935, s. 8-18; por. także Festchirift zur Feier des 250 jährigen Wiederbestehens der katholischen Gemeinde in Brieg, hrsg. von P. Hadamczik, Brieg 1927, s. 5.

${ }^{8}$ G. Kersten, Geschichte der Schneider-Innung zu Brieg, Brieg 1927, s. 4.

${ }^{9}$ A. Schaube, Urkundliche Geschichte der Gründung und ersten Entwicklung der deutschen Stadt Brieg. Ein Beitrag zur Kolonisationsgeschichte Schlesiens, Breslau 1934, s. 72. 
dostrzegł wprawdzie, że w dokumencie fundacyjnym zastrzeżono, że - w zgodzie $\mathrm{z}$ dominikańskimi konstytucjami - konwent powinien liczyć co najmniej 12 zakonników, ale nie ukrywał, że w historii klasztoru bywały okresy, w których liczba przebywających $\mathrm{w}$ nim profesów nie sięgała tej liczby. Jako pierwszy z historyków brzeskiej fundacji, K. Eisert przywołał też w swym opracowaniu liczne grono zamieszkujących w niej zakonników i przypisał im określone funkcje $\mathrm{w}$ klasztorze ${ }^{10}$. Ustalenia te znalazły trwałe miejsce w niemieckojęzycznej historiografii Brzegu - wydane w ostatnich latach prace poświęcone historii Brzegu nie wnoszą do historii tamtejszych dominikanów nic ponad to, co zdołał ustalić K. Eisert ${ }^{11}$.

Autorzy polscy (nie licząc bardzo skąpych wypowiedzi nowożytnych historyków dominikańskich i bazującego na nich $\mathrm{S}$. Barącza $\mathrm{OP}$ ) zajęli się historią klasztoru brzeskiego dopiero po II wojnie światowej. Najwięcej uwagi poświęcił mu J. Kłoczowski w pracy traktującej o historii klasztorów dominikańskich na Śląsku w XIII-XIV w. ${ }^{12}$ oraz rozprawce poświęconej kwestii reformy polskich klasztorów dominikańskich $\mathrm{w}$ późnym średniowieczu ${ }^{13}$. Brzescy zakonnicy pojawiają się także w opracowaniach o charakterze słownikowym i biograficznym ${ }^{14}$, w pracach traktujących o średniowiecznym szkolnictwie dominikańskim na ziemiach polskich ${ }^{15}$; dzięki badaniom K. Zawadzkiej znamy również zasoby i losy ich zbiorów bibliotecznych ${ }^{16}$.

Z powyższego przeglądu widać wyraźnie, że podstawowym i najpełniejszym do dziś opracowaniem historii klasztoru w Brzegu pozostaje licząca blisko 60 lat praca K. Eiserta. Mimo niezaprzeczalnej wartości poczynionych w niej ustaleń

${ }^{10}$ K. Eisert, Das Dominikanerkloster in Brieg (1336-1545), „Archiv für Schlesische Kirchengeschichte", 18 (1960) s. 70-94.

${ }^{11}$ Zob. np. W. Irgang, Ältere Geschichte der Stadt Brieg in ihrem schlesischen Umfeld, Goslar 1988; także: Schlesisches Städtebuch, hrsg. H. Stoob, P. Johanek, Stuttgart-Berlin-Köln 1995, s. $52-57$.

${ }^{12}$ Kłoczowski, Dominikanie polscy na Ślasku w XIII-XIV wieku, passim.

${ }^{13}$ Tenże, Reforma polskiej prowincji dominikańskiej w XV-XVI wieku, „Roczniki Humanistyczne”, 4 (1953) nr 4, s. 45-92; w niniejszej pracy korzystałem z przedruku tej publikacji w: J. Kłoczowski, Polska prowincja dominikańska w średniowieczu i Rzeczypospolitej Obojga (wielu) Narodów, Poznań 2008, s. 187-214.

${ }^{14}$ Zob. np. W. Bucichowski, Lista lektorów dominikańskich prowincji polskiej od erygowania prowincji (1225) do roku 1525, „Przegląd Tomistyczny”, 6-7 (1997) s. 45-231.

${ }^{15} \mathrm{Z}$ bogatej literatury poświęconej dziejom szkół polskich dominikanów zob. zwłaszcza P. Kielar, Organizacja szkolnictwa dominikańskiego w XIV wieku, „Studia Philosophiae Christianane”, 5 (1969) nr 1, s. 304-318; tenże, Studia nad kultura szkolna i intelektualna dominikanów prowincji polskiej w średniowieczu. I. Powstanie i rozwój organizacji szkolnej dominikanów w Polsce w XIII-XIV wieku, w: Studia nad historia dominikanów w Polsce 1222-1972, t. 1, red. J. Kłoczowski, Warszawa 1975, s. 392-420; K. Kaczmarek, Szkoły i studia polskich dominikanów w okresie średniowiecza, Poznań 2005; T. Gałuszka, Szkolnictwo konwentualne i partykularne w strukturach polskiej prowincji dominikanów XIV stulecia. Nowe ujęcie w świetle nowych źródel, „Roczniki Historyczne” (dalej: RH), 78 (2012) s. 191-211.

${ }^{16}$ K. Zawadzka, Biblioteki klasztorne dominikanów na Ślasku (1239-1810), Wrocław 1999, s. $75-78$. 
ma ona istotną wadę, jaką jest ograniczona podstawa źródłowa - autor oparł swe rozważania głównie na zachowanych do naszych czasów dokumentach brzeskich dominikanów ${ }^{17}$, a ze źródeł aktowych wykorzystał nekrolog konwentu ${ }^{18}$. K. Eisert nie znał natomiast podstawowych dziś przekazów do badań nad historią klasztorów wchodzących w skład polskiej prowincji dominikanów, to znaczy formularza dokumentów polskich prowincjałów z XIV-XV w., a także protokołów z posiedzeń kapituł prowincji. Pominięcie pierwszego z nich jest zupełnie niezrozumiałe, bowiem edycja tego źródła ukazała się kilkadziesiąt lat przez wydaniem pracy $\mathrm{K}$. Eiserta ${ }^{19}$. Inaczej ma się sprawa protokołów z posiedzeń kapituł polskiej prowincji dominikańskiej - K. Eisert nie mógł z nich skorzystać ponieważ w chwili publikacji jego pracy, ich zawartość była nieznana historykom. Pierwsze, mocno zresztą uszkodzone, zapiski z posiedzeń władz polskiej prowincji dominikańskiej odnalazł w latach 60. XX w. dominikański historyk, P. Kielar OP, który w 1969 r. wydał pracę zawierającą tekst dwóch XIV-wiecznych fragmentów takich protokołów ${ }^{20}$, zaś właściwa edycja średniowiecznych akt polskiej prowincji dominikańskiej ukazała się staraniem R. Madury OP w roku $1970^{21}$. Wielki przełom w badaniach nad protokołami z posiedzeń kapituł polskich dominikanów dokonał się w ostatnich latach za sprawą T. Gałuszki OP i M. Zdanka, którzy odnaleźli i wydali drukiem nieznane dotąd fragmenty protokołów z obrad władz prowincji ${ }^{22}$. Odkrycia te - niezwykle cenne z uwagi na fakt, że udostępnione przez wymienionych autorów zabytki pochodzą z XIV stulecia - mają ogromne znaczenie dla obecnych i przyszłych studiów nad klasztorami Braci Kaznodziejów, w tym (jak zobaczymy) domem w Brzegu. Dla badań nad konwentem brzeskim materiały te są szczególnie wartościowe, bowiem ich zawartość pozwala oświetlić kwestię słabo dotąd w odniesieniu do tego domu rozpoznaną, to znaczy jego stan osobowy w całym (skądinąd krótkim na tle innych klasztorów) okresie jego funkcjonowania. Spróbujmy zatem przy pomocy tych (i innych) źródeł odtworzyć ludzkie zasoby konwentu w Brzegu i wyciągnąć na tej podstawie ogólniejsze wnioski dotyczące jego wewnętrznej struktury.

${ }^{17}$ Zob. Urkunden der Stadt Brieg (dalej: USB), hrsg. von C. Grünhagen, Breslau 1870 (Codex Diplomaticus Silesiae, 9. Bd).

${ }^{18}$ Mortuarz klasztoru Św. Krzyża nie został dotąd wydany drukiem; jego rękopis jest obecnie przechowywany w Oddziale Rękopisów Biblioteki Uniwersyteckiej we Wrocławiu, sygn. IV F 174: Obituarium (Calendarium) conventus Bregensis (dalej: Obituarium).

${ }^{19}$ Zob. Zbiór formut zakonu dominikańskiego prowincji polskiej z lat 1338-1411 (dalej: ZF), wyd. J. Fijałek, „Archiwum Komisji Historycznej”, 12 (1919-1938) s. 219-428

${ }^{20}$ Kielar, Organizacja szkolnictwa dominikańskiego w XIV wieku, passim.

${ }^{21}$ Acta Capitulorum Provinciae Poloniae Ordinis Praedicatorum (dalej: ACPP), t. 1, ed. R.M. Madura, Romae 1970.

${ }^{22}$ T. Gałuszka, Fragment akt kapituły prowincjalnej dominikanów polskich z lat dziewięćdziesiatych XIV wieku. Studium historyczne i edycja tekstu, RH, 79 (2013) s. 119-145; tenże, Fragmenty czternastowiecznych akt kapitut prowincjalnych dominikanów polskich $w$ zbiorach Bayerische Staatsbibliothek w Monachium. Kapituła prowincjalna w Opatowcu w 1384 r., „Studia Źródłoznawcze”, 51 (2013) s. 107-122; M. Zdanek, Fragment akt kapituly prowincjalnej dominikanów polskich z 1338 roku, RH, 76 (2010), s. 263-276. 
Dominikańskie konstytucje, a także uchwały kapituł generalnych jasno określały wewnętrzną strukturę konwentów i zasady ich funkcjonowania. Każdy dom zakonny musiał liczyć co najmniej 12 zakonników, którymi kierował przeor wybierany przez upoważnionych do tego zakonników na posiedzeniu klasztornej kapituły. W wyjątkowych sytuacjach, na przykład w obliczu spadku liczby zakonników w klasztorze poniżej konstytucyjnego minimum 12 braci, prawo wskazania przełożonego konwentu przechodziło na władze prowincji. Zakonne ustawy przewidywały też obecność w każdym konwencie lektora odpowiedzialnego za intelektualną formację braci, ale - zwłaszcza w mniejszych klasztorach - przepisu tego nie zawsze przestrzegano ${ }^{23}$. W dobie średniowiecza każdy klasztor prowadził własny nowicjat, a kapituły generalne zakonu regularnie przypominały przeorom o ciążącym na nich obowiązku pozyskiwania nowych braci i groziły karami (do zdjęcia z urzędu włącznie) tym, którzy zaniedbaliby tego obowiązku ${ }^{24}$. Praktykę tę zmieniono dopiero w dobie reform Soboru Trydenckiego, kiedy na terenie każdej prowincji wyznaczono wybrane klasztory i upoważniono je do prowadzenia naboru nowicjuszy zarówno na ich własne potrzeby, jak i na potrzeby innych klasztorów ${ }^{25}$. W przeciwieństwie do starych zakonów mniszych, w których funkcje pełnione przez braci miały w praktyce dożywotni charakter, dominikanie przestrzegali zasady kadencyjności urzędów i stosowali systematyczną rotację na stanowiskach związanych z zarządzaniem zarówno pojedynczymi klasztorami, jak i większymi jednostkami organizacyjnymi zakonu w rodzaju kontrat czy prowincji. W odróżnieniu od starszych „feudalnych” wspólnot, dominikanie (i inni mendykanci) zrezygnowali też z respektowania zasady „stałości miejsca” (stabilitas loci) i często przenosili zakonników między klasztorami - praktycznie każda kapituła generalna, a także kapituły poszczególnych prowincji wydawały kilkadziesiąt (lub więcej) asygnat dla braci, kierując ich do wybranych domów i zlecając im w ich nowych miejscach zamieszkania określone obowiązki.

$\mathrm{Na}$ takich samych zasadach funkcjonował - rzecz jasna - także konwent w Brzegu. Skąd przybyli do miasta pierwsi dominikanie, tego niestety nie wiemy, choć (zob. niżej) z uwagi na uchwytne także w późniejszym okresie związki łączące te domy zakonne wolno podejrzewać, że jakaś część pierwotnej obsady klasztoru mogła się rekrutować z wrocławskiego konwentu św. Wojciecha, który był w okresie średniowiecza prawdziwą „kuźnią kadr” dla pozostałych klasztorów dominikańskich na Śląsku ${ }^{26}$. Nie ma powodu wątpić, że wkrótce po osiedleniu się w Brzegu dominikanie uruchomili własny nowicjat, do którego wstępowali kandydaci z miasta i jego okolic. Warto pamiętać o tym, że w przeciwieństwie do wielu innych ośrodków, w których dominikanie pojawili się bardzo wcześnie,

${ }^{23}$ Zob. Kaczmarek, Szkoły i studia polskich dominikanów w okresie średniowiecza, s. 149-152; ostatnio podtrzymał tę opinię także Gałuszka, Szkolnictwo konwentualne i partykularne, s. 195.

${ }^{24}$ Zob. np. Acta Capitulorum Generalium Ordinis Praedicatorum, t. 2, s. 445.

${ }^{25} \mathrm{~W}$ tej sprawie K. Kaczmarek, Wprowadzenie, w: Metryka dominikanów poznańskich 15761815, wyd. K. Kaczmarek, Poznań 2016, s. V-VI.

${ }^{26}$ Zob. Kaczmarek, Konwent dominikanów wrocławskich w późnym średniowieczu, s. 40-52. 
w latach przypadających na lokację tych miast, w Brzegu zakonnicy zamieszkali niemal 100 lat po nadaniu temu ośrodkowi praw miejskich ${ }^{27}$; przybywali zatem do miasta ukształtowanego pod względem prawnym, rozwiniętego gospodarczo i posiadającego świadome swych potrzeb religijnych zaplecze społeczne ${ }^{28}$. Zachowane do naszych czasów dokumenty pokazują zresztą, że klasztor szybko nawiązał bliskie stosunki z miastem, a jego mieszkańcy wspierali go nadaniami i korzystali z możliwości sepultury, traktując najwyraźniej pochówek w należącym do braci kościele jako wyraz duchowych więzi łączących ich z zakonem ${ }^{29}$. Nie jest więc dziełem przypadku, że już w XIV w. wśród brzeskich dominikanów widzimy przedstawicieli miejscowego patrycjatu - wiadomo, że w połowie tego stulecia w konwencie przebywali Mikołaj oraz Paweł, synowie mieszczanina z Brzegu, Mikołaja Grunenberga ${ }^{30}$.

$\mathrm{Z}$ tego najstarszego okresu funkcjonowania klasztoru potrafimy jednak przywołać z imienia tylko niewielkie grono braci zamieszkujących brzeską fundację. $\mathrm{Z}$ uwagi na lakoniczny charakter tych wzmianek trudno przy tym powiedzieć, czy osoby te zamieszkiwały dom w Brzegu od chwili wstąpienia do nowicjatu, czy też zostały doń skierowane z innych klasztorów, na mocy decyzji władz prowincji. Oprócz znanego już (zob. wyżej) pierwszego przeora konwentu, brata Szymona (1342 r.), znamy jego - chyba bezpośredniego - następcę, którym był Wilhelm, wzmiankowany w źródłach pod rokiem $1344^{31}$. Z szeregowych zakonników brzeskich przekazy wymieniają Mikołaja Cosbara (Cosbora), który w 1348 r. pojawia się w korespondencji skierowanej przez generała zakonu dominikańskiego do polskiego prowincjała i przeora klasztoru w Brzegu w charakterze uciekiniera z zakonu, proszącego o wybaczenie win i ponowne przyjęcie do wspólnoty ${ }^{32}$. Kilkadziesiąt lat później (1372 r.) jeden z brzeskich dominikanów - Jan Sculteti został decyzją ówczesnego prowincjała, Jana Teutonicusa z Brzegu, przeniesiony ze swego macierzystego konwentu do klasztoru św. Wojciecha we Wrocławiu ${ }^{33}$. Pod sam koniec XIV w. (1399 r.) w źródłach pojawia się także brat Wawrzyniec z Brzegu, pełniący ówcześnie funkcję zakrystianina w klasztorze w Opolu ${ }^{34}$.

${ }^{27} \mathrm{Na}$ ten temat zob. Irgang, Ältere Geschichte der Stadt Brieg, s. 117-123.

${ }^{28} \mathrm{O}$ rozwoju przestrzennym Brzegu, jego ustroju i rozwoju miasta w XIII i XIV w. zob. zwłaszcza W. Dziewulski, Brzeg od lokacji na prawie zachodnim do wygaśnięcia dynastii Piastów (12471675), w: Brzeg. Dzieje, gospodarka, kultura, red. W. Dziewulski, Opole 1975, s. 32-142; także J. Majewski, Uwarunkowania rozwoju przestrzennego miasta Brzegu, w: Szkice brzeskie, t. 1, red. D. Tomczyk, Opole 1981, s. 7-26; P. Kubów, Brzeg doby feudalnej w świetle badań archeologicznych przeprowadzonych w latach 1966-1976, w: Szkice brzeskie, t. 1, red. D. Tomczyk, Opole 1981, s. $27-57$.

${ }^{29}$ USB, passim.

${ }^{30}$ USB, s. 48: nr 334; Eisert, Das Dominikanerkloster in Brieg (1336-1545), s. 82.

${ }^{31}$ Archiwum Państwowe w Toruniu, sygn. Klasztor dominikanów 23; pominął go Eisert, Das Dominikanerkloster in Brieg (1336-1545), passim.

${ }^{32}$ ZF: nr 157 i 159; pominął go Eisert, Das Dominikanerkloster in Brieg (1336-1545), passim.

${ }^{33}$ ZF: nr 151; pominął go Eisert, Das Dominikanerkloster in Brieg (1336-1545), passim.

${ }^{34}$ Biblioteka Uniwersytetu Wrocławskiego. Oddział Rękopisów (dalej: BUW), sygn. IV F 221, fol. 46r. 
Obok tych, w gruncie rzeczy niemal anonimowych, zakonników jeszcze w XIV stuleciu w źródłach pojawia się jednak kilku innych dominikanów z Brzegu, którzy w przeciwieństwie do wyżej wymienionych odegrali znaczącą rolę w życiu zarówno własnego konwentu, jak i całej polskiej prowincji dominikańskiej. Chyba najważniejszą z tych osób był brat Henryk Bitterfeld. Według ustaleń czeskiego historyka dominikańskiego - V. Koudelki OP - pochodził z osiadłej w Brzegu flamandzkiej rodziny o nazwisku Venken. Pod odbyciu nowicjatu w klasztorze brzeskim, Henryk podjął naukę w którejś ze szkół dominikańskich na terenie kontraty śląskiej, a następnie wyjechał na wyższe studia do Pragi. Tam występuje w roku 1386 z tytułem prezentata teologii, zaś w $1391 \mathrm{r}$. widzimy go $\mathrm{z}$ tytułem magistra in sacra pagina. Nie wydaje się, by poza wstępnym okresem zakonnego życia był silniej związany ze swoim macierzystym klasztorem, choć ostatnie lata jego życia są pełne luk - pod sam koniec XIV w. przebywał zapewne w klasztorze krakowskim, był spowiednikiem królowej Jadwigi i napisał dla niej traktat o życiu kontemplacyjnym i czynnym ${ }^{35}$. Nie wiemy dokładnie kiedy zmarł, jego zgon należy prawdopodobnie datować około 1404/1405 r. ${ }^{36} \mathrm{Z}$ zakonników brzeskich ostatniej ćwierci XIV w. wyróżnia się także wspomniany wyżej Jan Teutonicus. Nie wiemy, kiedy dokładnie wstąpił do zakonu, jednak z uwagi na chronologię późniejszych wydarzeń z jego udziałem wolno założyć, że musiał należeć do jednego z pierwszych pokoleń braci zamieszkujących brzeski konwent. Po raz pierwszy pojawia się w źródłach w roku 1370, jako definitor prowincji polskiej $\mathrm{i}$ jej reprezentant na posiedzeniu kapituły generalnej obradującej w klasztorze $\mathrm{w}$ Walencji ${ }^{37}$. Pełniona przez Jana funkcja oznacza, że zakonnik należał już wtedy do grona kilku najważniejszych i najbardziej wpływowych zakonników uczestniczących w zarządzaniu prowincją. W tym samym roku Jan występuje z tytułem przeora klasztoru w Słupsku ${ }^{38}$. Także w 1370 r. na kapitule prowincji w Chełmnie powierzono mu funkcję prowincjała, którą sprawował aż 9 lat: wiemy, że przewodniczył kilku kapitułom prowincji i był rzecznikiem wprowadzenia w klasztorach polskich reformy obserwanckiej ${ }^{39}$. Bez wątpienia to z jego inicjatywy obrady kolejnej kapituły prowincji (1371 r.) odbyły się w brzeskim konwencie św. Krzyża; akta tej kapituły nie zachowały się jednak do naszych czasów ${ }^{40}$.

${ }^{35}$ Zob. Henricus Bitterfeld de Brega OP, Tractatus de vita contemplativa et activa, ed. B. Mazur, L. Seńko, R. Tatarzyński, Warszawa 2003.

${ }^{36} \mathrm{Z}$ bardzo obfitej literatury poświęconej Henrykowi zob. zwłaszcza V. Koudelka, Heinrich von Bitterfeld (+ ca 1405), Professor an der Universität Prag, „Archivum Fratrum Praedicatorum” (dalej: AFP), 23 (1953) s. 5-65; A. Strzelecka, Henryk z Bitterfeld, w: Polski Stownik Biograficzny (dalej: PSB), t. 9, Wrocław-Warszawa-Kraków 1960-1961, s. 420; M. Papuzińska-Mill, Henryk Bitterfeld z Brzegu, „Przegląd Tomistyczny”, 4 (1988) s. 178-188; Kaczmarek, Szkoty i studia polskich dominikanów w okresie średniowiecza, s. 407-408: nr 19.

${ }^{37}$ Acta Capitulorum Generalium Ordinis Praedicatorum, t. 2. Ab anno 1304 usque ad annum 1378, ed. B.M. Reichert, Romae 1899, s. 417 (Monumenta Ordinis Praedicatorum Historica, t. 2).

${ }^{38}$ Tamże.

${ }^{39}$ Zob. J. Kłoczowski, Jan z Brzegu, PSB, t. 10, Wrocław-Warszawa-Kraków 1962-1964, s. 443; pominął go Eisert, Das Dominikanerkloster in Brieg (1336-1545), passim.

${ }^{40}$ ACPP, s. 14. 
Pod sam koniec XIV stulecia w klasztorze w Brzegu pojawił się brat Henryk Strupicz. Nie wiadomo, czy był wychowankiem brzeskiego nowicjatu, jednak z uwagi na fakt, iż nieliczne wzmianki o jego życiu wiążą jego działalność $\mathrm{z}$ terenem śląskiej kontraty prowincji, nie da się tego wykluczyć. Henryk działał na niwie szkolnej - w 1384 r. widzimy go w charakterze wykładowcy w partykularnej szkole „sztuk” (artium) w Legnicy, zaś kilkanaście lat później (1399 r.) odnajdujemy go w Brzegu, gdzie zakonnik występuje jako lektor w konwentualnej szkole teologii. Do zastanowienia daje zwłaszcza ostatnia wzmianka, bowiem dowodzi ona gruntownego wykształcenia teologicznego zakonnika, które mógł on w ówczesnych warunkach (brak Studium Generalnego w prowincji polskiej) zdobyć tylko w którejś z zagranicznych szkół zakonnych ${ }^{41}$. W podobnym co brat Henryk charakterze widzimy w klasztorze brzeskim także Jana Oczko, który w 1399 r. również występuje w źródłach jako lektor teologii w tym konwencie. Podobnie jak wyżej wymieniony musiał on zatem przejść drogę intensywnych studiów filozoficznych i teologicznych, których szczegóły jednak nie znamy. Wiemy tylko, że w już w 1378 r. Jan Oczko działał jako lektor „sztuk” w partykularnej szkole dominikanów w Legnicy, a niewiele lat później (1384 r.) zakonnik wystąpił w źródłach w charakterze kaznodziei generalnego. Funkcja lektora w Brzegu była zapewne ostatnią w jego karierze, bowiem pod rokiem 1399 nekrolog konwentu brzeskiego informuje o zgonie zakonnika ${ }^{42}$. Znaczącą postacią wśród dominikanów brzeskich schyłku XIV w. był też zapewne Jan z Gliwic. Nie wiadomo, czy klasztor Św. Krzyża był jego macierzystym domem zakonnym. Po raz pierwszy Jan występuje w źródłach w roku 1383 jako student w Studium Generalnym dominikanów w Kolonii. Biorąc ten fakt pod uwagę można przyjąć, że w tym czasie musiał mieć za sobą co najmniej kilkuletni staż życia zakonnego i ukończoną naukę w szkołach partykularnych na terenie prowincji, zapewne (choć to domysł, dla którego nie ma bezpośredniego oparcia w źródłach) w którymś ze studiów położonych $\mathrm{w}$ granicach kontraty śląskiej. Po powrocie ze studiów zagranicznych (1384 r.) widzimy Jana w klasztorze w Brzegu w charakterze lektora Sentencji Piotra Lombarda. Na początku XV w. zakonnik opuścił Brzeg, przeniósł się do klasztoru we Wrocławiu i w latach 1404-1415 działał tam w charakterze inkwizytora diecezji wrocławskiej ${ }^{43}$.

${ }^{41}$ Gałuszka, Fragmenty czternastowiecznych akt kapitut prowincjalnych dominikanów polskich w zbiorach Bayerische Staatsbibliothek w Monachium, s. 120; na jego temat także Kaczmarek, Szkoły i studia polskich dominikanów w okresie średniowiecza, s. 408: nr 20; pominął go Eisert, Das Dominikanerkloster in Brieg (1336-1545), passim.

${ }^{42}$ Obituarium fol. 48r; Kielar, Organizacja szkolnictwa dominikańskiego w XIV wieku, s. 317; Bucichowski, Lista lektorów dominikańskich prowincji polskiej, s. 132-133, nr 443; Kaczmarek, Szkoły i studia polskich dominikanów w okresie średniowiecza, s. 411, nr 34; Gałuszka, Fragmenty czternastowiecznych akt kapitut prowincjalnych dominikanów polskich, s. 120; pominął go Eisert, Das Dominikanerkloster in Brieg (1336-1545), passim.

${ }^{43}$ G.M. Löhr, Breslauer Dominikaner des 15. Jahrhundert auf auswärtigen Hochschulen, AFP, 13 (1943) s. 169; Z. Mazur, Powstanie i działalność inkwizycji dominikańskiej na Ślasku w XIV wieku, „Nasza Przeszłość”, 39 (1973) s. 186-187; Bucichowski, Lista lektorów dominikańskich prowincji polskiej, s. 140: $\mathrm{nr}$ 496; Kaczmarek, Szkoty i studia polskich dominikanów w okresie średnio- 
Informacje o pierwszych pokoleniach brzeskich dominikanów są - jak widać - skąpe. Z XIV w. nie dysponujemy żadnymi zestawieniami zakonników zamieszkujących ten dom, wiadomości o nich są nieliczne, dość przypadkowe i rozproszone po różnych źródłach. Mimo to można na ich podstawie sformułować istotny, w zasadzie niedostrzegany w dotychczasowych badaniach wniosek: mimo, że konwent brzeski został sformowany dopiero w połowie XIV stulecia, w ciągu niewielu lat funkcjonowania wyrósł na znaczący ośrodek szkolny na terenie śląskiej kontraty prowincji. Wiadomo, że - w przeciwieństwie do wielu innych domów, dla których nie zachowały się takie wzmianki - w jego murach działało konwentualne studium teologii, zatrudniające u schyłku XIV stulecia (1399 r.) aż dwóch lektorów. Wagę Brzegu jako znaczącego ośrodka szkolnego dominikanów na Śląsku wzmacnia dodatkowo fakt działania w tym klasztorze szkół partykularnych: wzmianka o przebywającym w klasztorze w 1384 r. magistrze studentów rodzi podejrzenie o funkcjonowaniu tam szkoły filozoficznej, zaś nominacja na lektora Sentencji dla brata Jana z Gliwic dowodzi działalności w Brzegu partykularnej szkoły teologii.

Ze względu na fakt, iż z XIV w. zachowały tylko fragmenty protokołów z posiedzeń polskiej prowincji dominikańskiej trudno powiedzieć coś pewnego o kontaktach konwentu brzeskiego z innymi domami na terenie kontraty śląskiej, czy - szerzej - całej prowincji. Dwie zachowane do naszych czasów wzmianki o zakonnikach z Brzegu obecnych w innych klasztorach (Wawrzyniec działający jako zakrystianin w klasztorze opolskim i Jan Sculteti przeniesiony z Brzegu do wrocławskiego konwentu św. Wojciecha), to zbyt skąpy materiał, by odpowiedzieć na pytanie o skalę i charakter tych kontaktów. Można jedynie w formie hipotezy wypowiedzieć pogląd mówiący, iż u schyłku XIV w. konwent brzeski był na tyle liczny, że można było z niego bez uszczerbku dla miejscowego zespołu braci przenosić wybranych zakonników do innych domów prowincji. Powyższe obserwacje upoważniają do rewizji sadu wypowiedzianego przez K. Eiserta, który uważał, że konwent brzeski nie był zbyt liczny. Naszym zdaniem jego potencjał osobowy był większy niż dotąd podejrzewano, głównie ze względu na działające w nim szkoły, do których z uwagi na ich partykularny charakter poza zakonnikami z samego Brzegu musieli też uczęszczać bracia z innych klasztorów, najpewniej $\mathrm{z}$ domów położonych $\mathrm{w}$ granicach śląskiej kontraty prowincji.

Znacznie więcej informacji o dominikanach z Brzegu posiadamy dopiero z XV stulecia. Dla badań nad tym fragmentem dziejów konwentu dysponujemy o wiele solidniejszą podstawą źródłową: bracia zaczynają się pojawiać w większej liczbie w przekazach o charakterze dokumentowym, znamy też - praktycznie nieobecne $\mathrm{w}$ dotychczasowych badaniach nad tym klasztorem - protokoły z posiedzeń kapituł prowincji, posiadamy wreszcie ważne dla tematu przekazy spisane we wrocławskim konwencie św. Wojciecha, które (zob. niżej) mają istotne znaczenie dla badań nad stanem osobowym konwentu brzeskiego w końcu XV i na początku XVI stulecia.

wiecza, s. 409: nr 26; Gałuszka, Fragmenty czternastowiecznych akt kapituł prowincjalnych dominikanów polskich, s. 121; pominął go Eisert, Das Dominikanerkloster in Brieg (1336-1545), passim. 
Jako pierwszy z brzeskich dominikanów pojawia się w tym okresie w źródłach brat Jan Cerdonis, ówczesny profes we Lwowie ${ }^{44}$, o którym jednak nie sposób powiedzieć nic więcej. Obszerniejszy wykaz braci zamieszkujących brzeską fundację pochodzi z dokumentu wydanego 15 stycznia $1414 \mathrm{r}$. zawierającego darowiznę dla dominikanów od Katarzyny Brigerynne, wdowy po mieszczaninie brzeskim Janie Jenischu. W dyplomie tym odnajdujemy czterech zakonników sprawujących kierownicze funkcje w klasztorze: przeora Andrzeja Swidnicza, lektora Gerarda Comitisa, nieznanego z imienia podprzeora o przydomku Twarg i zakrystianina Mikołaja Gladiatorisa, a także trzech innych braci bez wyraźnie określonych funkcji, należących - być może - do starszyzny zasiadającej w klasztornej radzie (Mikołaj Sculteti, Jan Sculteti i Mikołaj Gaudeamus) ${ }^{45}$. Zważywszy na podniesioną wcześniej okoliczność (istotna rola klasztoru w Brzegu na szkolnej mapie kontraty śląskiej i kierowanie zakonników z Brzegu do innych domów) trudno podejrzewać, by wymienieni w tym dyplomie bracia stanowili w początkach XV w. całą obsadę konwentu Św. Krzyża. Dom w Brzegu musiał w tym czasie liczyć co najmniej kikunastu zakonników, wśród których (poza wyżej wymienionymi) było zapewne także grono nowicjuszy, pewna liczba konwersów, a także - być może - jacyś uczniowie w działających w Brzegu szkołach. O tym, że takie odczytanie zawartości dokumentu z 1414 r. jest właściwe, przekonuje podobny akt wydany kilkadziesiąt lat później - w dyplomie z 4 września 1458 r. także występuje tylko kilku funkcyjnych zakonników (przeor Jan Gloger, podprzeor Jan Coci oraz zakrystianin Jan Piscatoris, a także profesi bez określonej funkcji: Jan Sartoris, Ludwik Sartoris oraz Jan Cengir), ale dokument mówi wprost, że $\mathrm{w}$ klasztorze przebywają także jacyś inni, nieznani nam $\mathrm{z}$ imienia, bracia ${ }^{46}$. Nieco inaczej została skonstruowana lista zakonników z Brzegu na dyplomie wystawionym w dniu 28 września 1459 r. Akt ten wzmiankuje najpierw przeora Jana Mechewicza, podprzeora Jakuba Coci (Kocha) oraz kaznodzieję konwentu Jana Strelena, ale w następnej kolejności - inaczej niż wcześniej cytowane dokumenty - wymienia kilku braci z zachowaniem hierarchii posiadanych przez nich święceń. Najpierw przywołanych zostało pięciu zakonników posiadających święcenia kapłańskie (Jan Piscatoris, Jan Sartoris, Ludwik Sartoris, Andrzej Ortulanus i Marcin Guterleye), a po nich wspomniany został diakon Jan Bewthum oraz jeden brat, Paweł Mechewicz, jak podejrzewał K. Eisert, młodszy brat znanego z 1458 r. przeora Jana Mechewicza ${ }^{47}$, który w hierarchii konwentu zajmował najwyraźniej poślednie miejsce, zapewne z tego względu, że miał niewielki staż życia we wspólnocie i nie wkroczył jeszcze na drogę święceń ${ }^{48}$. Analogie z przekazami powstałymi we wrocławskim konwencie św. Wojciecha, gdzie stosowa-

${ }^{44}$ Zob. Archiwum Polskiej Prowincji Dominikanów w Krakowie, sygn. Lw 11; także: Akta grodzkie i ziemskie z czasów Rzeczypospolitej Polskiej z archiwum tak zwanego bernardyńskiego we Lwowie, t. 2, Lwów 1870, nr 34.

${ }^{45}$ USB, s. 104: nr 728; Eisert, Das Dominikanerkloster in Brieg (1336-1545), s. 85.

${ }^{46}$ Tamże, s. 139: nr 978; Eisert, Das Dominikanerkloster in Brieg (1336-1545), s. 87.

${ }^{47}$ Eisert, Das Dominikanerkloster in Brieg (1336-1545), s. 87.

${ }^{48}$ USB, s. 139-140: nr 980; wszystkich tych zakonników wymienia także Eisert, Das Dominikanerkloster in Brieg (1336-1545), s. 87. 
no podobny schemat przy zestawianiu wykazów braci przebywających w danym czasie $\mathrm{w}$ klasztorze ${ }^{49}$, pozwalają domyślać się, że poza wymienionymi $\mathrm{w}$ dokumencie profesami w klasztorze w Brzegu mogła jeszcze przebywać pewna liczba nowicjuszy oraz braci służebnych, czyli konwersów. Inne źródła dokumentowe z XV w. mają mniejsze znaczenia dla odtworzenia stanu osobowego konwentu w dwóch dokumentach z 14 kwietnia i 7 czerwca 1467 r. odnajdujemy znanego nam już przeora Jana Mechewicza, który - wszystko na to wskazuje - po krótkiej przerwie w końcu lat 50. XV stulecia ponownie objął kierownictwo konwentu ${ }^{50}$.

Dla odtworzenia środowiska brzeskich dominikanów w XV w. o wiele większe znaczenie od przekazów dokumentowych mają protokoły z posiedzeń kapituł polskiej prowincji dominikańskiej. Zachowały się one głównie dla 2. połowy tego stulecia i przynoszą sporo interesujących informacji o profesach zamieszkujących dom w Brzegu. Pierwsze takie wzmianki odnajdujemy w protokole kapituły obradującej w 1447 r. w Sieradzu. W jej aktach odnajdujemy w charakterze definitora brata Michała Recesta ówczesnego przeora konwentu Św. Krzyża, a także trzech zakonników skierowanych do Brzegu na mocy asygnat wydanych przez władze prowincji: brat Michał oraz Andrzej Pistoris z konwentu w Tczewie mieli się tam udać w charakterze zwykłych profesów, zaś Łukasz Pellificis został doń asygnowany pro praedicatore Teutonicorum, czyli kaznodziei głoszącego nauki w języku niemieckim ${ }^{51}$. Następne asygnaty do klasztoru brzeskiego pochodzą od kapituły zwołanej w roku 1458 do klasztoru w Poznaniu. W protokole z jej obrad znajdujemy wzmiankę o wysłaniu do Brzegu kolejnych trzech zakonników (Grzegorza Rimana, Stanisława Grete oraz Jana Zaskowica z klasztoru w Bolesławcu). Ponieważ żadnemu z nich nie została przypisana konkretna funkcja należy przyjąć, że wszyscy zostali przeniesieni do tego domu w charakterze zwykłych profesów ${ }^{52}$. Akty skierowania zakonników do klasztoru brzeskiego wystawiła też kapituła obradująca w 1465 r. w klasztorze sandomierskim. Ona również $-\mathrm{z}$ godną podziwu regularnością - przeniosła do tego domu trzech braci (Jana Cingulatorisa, Mikołaja Hermana i Jakuba Fabri), choć nie wiemy niestety jakie zakonnicy ci zamieszkiwali klasztory przed wysłaniem ich do konwentu Św. Krzyża $^{53}$. Zauważmy jednak, że - podobnie jak to było w 1458 r. - także kapituła z Sandomierza skierowała do Brzegu szeregowych profesów, których jedyne zadanie sprowadzało się zapewne do zasilenia chóru miejscowego konwentu, nie było natomiast wśród nich żadnych zakonników funkcyjnych.

Przywołując akta XV-wiecznych kapituł, w których znajdują się asygnaty dominikanów brzeskich trzeba też sięgnąć do protokołu kapituły łęczyckiej z roku 1461. W niej również odnajdujemy asygnatę profesa brzeskiego, ale w istotny sposób różni się ona od przywołanych wyżej postanowień kapituł z lat 1447, 1458 i 1465 . O ile bowiem te pierwsze mówiły wyłącznie o zakonnikach kierowanych do Brzegu z innych domów prowincji, to kapituła łęczycka jako jedyna wydała

\footnotetext{
${ }^{49}$ Kaczmarek, Konwent dominikanów wrocławskich w późnym średniowieczu, s. 205 i n.

${ }^{50}$ USB, s. 144: nr 1009 i 1011.

${ }^{51}$ ACPP, s. 26 i 29.

52 Tamże, s. 51.

${ }^{53}$ Tamże, s. 82.
} 
postanowienie przeciwnej treści, to znaczy asygnowała zakonnika z Brzegu (Mikołaja de Olsena) do konwentu w Świdnicy ${ }^{54}$. Dodajmy jednak, że (tak jak to miało miejsce w większości przywołanych wyżej przypadków) brat Mikołaj zmienił miejsce zamieszkania jako zwykły profes - nic nie wiadomo, by władze prowincji zleciły mu pełnienie w klasztorze świdnickim jakiejkolwiek funkcji.

W sumie więc, w XV-wiecznych protokołach z posiedzeń kapituł polskiej prowincji dominikańskiej odnajdujemy 10 zakonników, których można afiliować do klasztoru w Brzegu. Co istotne, z tych 10 osób aż 9 zostało przez władze prowincji skierowanych do klasztoru Św. Krzyża, a tylko 1 z nich miała opuścić ten konwent i przenieść się do Świdnicy. Biorąc pod uwagę powyższą okoliczność wolno w tym miejscu postawić hipotezę mówiącą, iż w XV w. (a przynajmniej w jego 2. połowie) konwent brzeski cierpiał na niedobory kadrowe, które starano się łagodzić przenosząc doń braci z innych klasztorów. Kierunki migracji tych zakonników są jednak trudne do odtworzenia, bowiem tylko w dwóch przypadkach odnajdujemy w aktach prowincji konkretne informacje o tym skąd pochodzą bracia kierowani do Brzegu (Tczew i Bolesławiec), a to zbyt mało by pokusić się o odpowiedź na pytanie o to, czyimi zasobami wzmacniano konwent Św. Krzyża. Można tylko podejrzewać, że brano przy tym pod uwagę kryterium językowe i kierowano do Brzegu zakonników, którzy posługiwali się językiem niemieckim. Zauważmy też, że w XV wieku z akt prowincji zupełnie znikają zakonnicy obecni w takich przekazach w stuleciu XIV, to znaczy personel brzeskich szkół partykularnych. Ich nieobecność w przekazach ze schyłkowych lat średniowiecza jest uderzająca: w żadnym ze znanych nam wykazów partykularnych szkół „sztuk”, filozofii bądź teologii, jakie w 2. połowie XV w. działały na terenie kontraty śląskiej klasztor w Brzegu nie występuje, choć inne klasztory śląskiej kontraty (Wrocław, Świdnica, Legnica, Racibórz, Ząbkowice, Głogów czy Bolesławiec pojawiają się w tych spisach z wielką regularnością ${ }^{55}$. Próżno też (zob. wyżej) szukać zakonników z klasztoru brzeskiego asygnowanych do innych domów prowincji w charakterze uczniów czy wykładowców działających w nich studiów; nie ma też takich braci wśród licznego grona polskich dominikanów kierowanych w późnym średniowieczu na studia zewnętrzne, do dominikańskich Studiów Generalnych na terenie Niemiec, Italii czy Francji ${ }^{56}$. Wygląda więc na to, że klasztor w Brzegu utracił w XV w. silną, jak się wydaje, pozycję na szkolnej mapie prowincji, jaką zajmował w poprzednim stuleciu. Poza jednostkowymi wręcz przykładami trudno też wskazać w tym konwencie braci, których u schyłku średniowiecza można by zaliczyć do jego elity umysłowej, nie widać wreszcie by brzescy profesi obejmowali w tym okresie (jak to miało miejsce w ostatniej ćwierci XIV w.) znaczące funkcje w strukturach zarządu prowincji w rodzaju prowincjałów czy defi-

${ }^{54}$ Tamże, s. 62; jego zgon w nieznanym bliżej roku odnotował nekrolog dominikanów wrocławskich. Zob. BUW, rkp. IV F 222, fol. 23.

${ }^{55} \mathrm{~W}$ tej sprawie zob. Kaczmarek, Szkoły $i$ studia polskich dominikanów w okresie średniowie$c z a$, s. 226, 245-246 i 259-261.

${ }^{56}$ Tamże, s. 377-382; por. także J. Kłoczowski, Ze zwiazków Polski z krajami zachodnimi u schytku średniowiecza. Studia zagraniczne dominikanów prowincji polskiej, w: Polska w Europie, red. H. Zins, Lublin 1968, s. 109-136. 
nitorów. Powód takiego stanu rzeczy wydaje się dość oczywisty - konwent brzeski poważnie ucierpiał w dobie wojen husyckich. Wiadomo, że wojska husytów w krótkim czasie $(1428,1430$ i 1432) trzykrotnie wkraczały do Brzegu plądrując miasto, profanując istniejące w nim kościoły i dopuszczając się mordów na jego mieszkańcach; w najazdach tych ucierpiał też klasztor Św. Krzyża ${ }^{57}$. Jak długo trwała naprawa poczynionych przez husytów szkód, tego nie wiemy, ale fakt, że w następnych latach trzeba było regularnie zasilać brzeską fundację zakonnikami z innych klasztorów każe podejrzewać, że możliwości ich rekrutowania do nowicjatu na terenie samego miasta były ograniczone. Zauważmy jednak, że w znanych nam protokołach kapituł polskiej prowincji dominikańskiej z 2. połowy XV w. nie odnajdujemy informacji o mianowaniu brzeskich przeorów przez władze prowincji, co byłoby czytelnym sygnałem, że liczebność konwentu spadła poniżej ustawowej (i zapisanej w dokumencie fundacyjnym tego klasztoru) liczby 12 braci. Z drugiej strony fakt regularnego posyłania do Brzegu profesów z innych domów pozwala domyślać się, że w 2. połowie XV w. liczba braci przebywających w konwencie Św. Krzyża nie była chyba wiele wyższa od tej wartości.

K. Eisert zauważył, że na - i tak chyba niezbyt imponujące - ludzkie zasoby konwentu brzeskiego bardzo destrukcyjny wpływ miały wydarzenia $\mathrm{z}$ samego początku XVI w., kiedy to wskutek pożaru zawalił się fragment miejskich murów, a z nim wkomponowana w fortyfikacje część zabudowy klasztornej; w efekcie tych wydarzeń pewna grupa zakonników musiała opuścić konwent ${ }^{58}$. Skutki tego rozproszenia brzeskiej wspólnoty były w następnych latach łagodzone przez kapituły prowincji, które - podobnie jak to miało miejsce po wojnach husyckich - wspomagały klasztor Św. Krzyża kierując doń zakonników z innych domów. Pierwsze takie asygnaty odnajdujemy w aktach kapituły ze Żnina z 1510 r., która wysłała do Brzegu dwóch zakonników: Mikołaja z konwentu w Cieszynie oraz brata Andrzeja, subdiakona $\mathrm{z}$ domu we Lwowie ${ }^{59}$. Po upływie dwóch kolejnych lat (1512 r.) kapituła cieszyńska ponownie wzmocniła obsadę klasztoru w Brzegu wysyłając doń w charakterze lektora i kaznodziei brata Marcina Tabernatorisa z nieznanego konwentu ${ }^{60}$. Dwóch kolejnych zakonników asygnowała do Brzegu kapituła łowicka w roku 1514: w charakterze kursora i kaznodziei miał się tam udać Andrzej z Opawy, zaś jako brat służebny (konwers) zamieszkał w Brzegu brat Andrzej z Ziębic (de Friberga $)^{61}$. W roku 1517 postanowieniem kapituły z Sieradza do Brzegu przeniesiono w charakterze lektora „sztuk” i kaznodziei brata Walentego z Ziębic ${ }^{62}$. Znamienne, że ruchy w przeciwną stronę (to znaczy przenoszenie zakonników z Brzegu do innych klasztorów) zdarzały się rzadziej. Akta kapituł z XVI w. notują ledwie dwa takie przypadki odnotowane w protokole kapituły chełmińskiej z 1519 r. - na mocy jej postanowień Jan z konwentu

${ }^{57}$ Dziewulski, Brzeg od lokacji na prawie zachodnim do wygaśnięcia dynastii Piastów (12471675), s. 44-45, także Eisert, Das Dominikanerkloster in Brieg (1336-1545), s. 87.

${ }^{58}$ Tamże, s. 90.

${ }^{59}$ ACPP, s. 180.

${ }^{60}$ Tamże, s. 192.

${ }^{61}$ Tamże, s. 209.

${ }^{62}$ Tamże, s. 239. 
w Brzegu miał się przenieść do klasztoru w Poznaniu, zaś inny profes z konwentu Św. Krzyża, brat Grzegorz [Jerzy?] Sartoris, został asygnowany do klasztoru w Krośnie Odrzańskim ${ }^{63}$. Polityka kapituł w zakresie asygnowania profesów do i z klasztoru brzeskiego była więc bardzo konsekwentna zarówno w XV jak i w 1. połowie XVI stulecia: znacznie więcej zakonników zostało przez kapituły wysłanych do Brzegu, znacznie zaś mniejszą liczbę tamtejszych profesów przeniesiono stamtąd do innych klasztorów, co - podkreślmy raz jeszcze - może świadczyć o tym, że konwent ten nie był specjalnie liczny i domagał się systematycznego wzmacniania zakonnikami z innych domów, zwłaszcza w tych momentach swych dziejów, gdy spadały nań nieszczęścia w rodzaju wojen czy klęsk żywiołowych. Przywołując asygnaty kapituł dla zakonników udających się do Brzegu w początkach XVI stulecia warto zwrócić uwagę na jeszcze jedną okoliczność - po długiej przerwie ponownie widzimy wśród nich braci pełniących funkcje nauczycielskie zarówno w konwentualnej szkole teologii, jak i w partykularnych studiach artium i teologii. Fakt ten świadczy o przywróceniu klasztorowi brzeskiemu rangi znaczącego ośrodka szkolnego na terenie śląskiej kontraty prowincji; zapewne należy łączyć go (zob. niżej) z prowadzoną w tym konwencie reformą życia wewnętrznego.

Poza wyżej omówionymi na stan osobowy brzeskiego konwentu dominikanów u schyłku średniowiecza duży wpływ wywarły jeszcze dwa wydarzenia z końca XV i 1. połowy XVI stulecia, to znaczy reforma obserwancka zaprowadzona $\mathrm{w}$ wybranych klasztorach prowincji, $\mathrm{w}$ tym $\mathrm{w}$ domu $\mathrm{w}$ Brzegu, a także postępy idei reformacyjnych - reforma luterańska została co prawda oficjalnie zaprowadzona w księstwie brzeskim dopiero w latach 30. XVI w., ale już wcześniej nowinki religijne docierały do miasta i samego klasztoru dominikanów, nie pozostając bez wpływu na dyscyplinę zakonników i ich życiowe postawy ${ }^{64}$.

Pierwsze próby reformowania klasztorów dominikańskich w duchu obserwanckim datują się jeszcze na schyłek XIV stulecia i związane są z osobą ówczesnego generała zakonu, Rajmunda z Kapui. W tym okresie zasięg reformy był jednak dość ograniczony, a próby jej wprowadzania do niektórych prowincji kończyły się niepowodzeniem. Należała do nich także prowincja polska, gdzie w 1399 r. podjęto nieudaną próbę zreformowania klasztoru w Poznaniu ${ }^{65}$. Skuteczniejsze zabiegi wokół przywracania w klasztorach surowszej dyscypliny podjęto dopiero w latach 30. XV w. na terenie Śląska - za rządów prowincjała Jana z Ząbkowic skutecznie zreformowano wrocławski konwent św. Wojciecha i uczyniono zeń najważniejszy ośrodek obserwancki, który miał być wzorem do naśladowania dla innych klasztorów ${ }^{66}$. Generalnie rzecz biorąc, reforma postępowała jednak powoli; niektóre klasztory nie chciały jej przyjmować, a te domy, które jej

${ }^{63}$ Tamże, s. 258-259.

${ }^{64}$ Dziewulski, Brzeg od lokacji na prawie zachodnim do wygaśnięcia dynastii Piastów (12471675), s. 50-53; Eisert, Das Dominikanerkloster in Brieg (1336-1545), s. 92-93.

${ }^{65}$ Zob. J. Kłoczowski, Reforma polskiej prowincji dominikańskiej w XV-XVI wieku, s. 191-192.

${ }^{66}$ Tamże, s. 192-194; ostatnio nowe ujęcie problemu dała A. Zajchowska, Między uniwersytetem a zakonem. Biografia i spuścizna pisarska dominikanina Jana z Ząbkowic (+1446), Warszawa 2013, s. 220-247. 
uległy po pewnym czasie musiały ją zaprowadzać ponownie. Wśród klasztorów poddanych dziełu odnowy życia znalazł się także dom w Brzegu. Po raz pierwszy próbowano w nim zaprowadzić obserwanckie porządki już w 1433 r. ${ }^{67}$, ale starania te nie przyniosły pożądanych efektów. Łatwo to zresztą zrozumieć - osłabionemu po wojnach husyckich konwentowi trudno było narzucić surowe rygory życia. Z odnowy konwentu Św. Krzyża jednak nie zrezygnowano i w następnych latach ponawiano zalecenia wprowadzenia w nim obserwancji - w $1441 \mathrm{r}$. Bartłomiej Texier, generał zakonu dominikańskiego, ustanowił byłego prowincjała i przeora wrocławskiego, Jana z Ząbkowic swym wikariuszem i polecił mu wprowadzenie reformy w klasztorze brzeskim ${ }^{68}$. Na wykazach reformowanych klasztorów dom w Brzegu występuje także w następnych latach: znamy zachowane w późnych odpisach streszczenia protokołów kapituł prowincji z końca XV w. (1486 i 1496), $\mathrm{w}$ których dom w Brzegu występuje w gronie innych zreformowanych klasztorów ${ }^{69}$, a także wystawiony w 1495 r. dokument potwierdzający przyjęcie przez klasztor brzeski obserwanckiego stylu życia ${ }^{70}$.

Fakt, iż dzieło odnowy życia zakonnego w klasztorze Św. Krzyża zostało powierzone dominikanom wrocławskim miał znaczący wpływ na społeczność tego konwentu - u schyłku XV i na początku XVI stulecia konwent w Brzegu był stale i w znaczącym stopniu zasilany kadrami konwentu św. Wojciecha. $Z$ tego okresu nie zachowały się co prawda protokoły z posiedzeń kapituł prowincji i trudno w efekcie śledzić te migracje zakonników w sposób ciągły, ale znane nam źródła proweniencji wrocławskiej pozwalają dość dokładnie odtworzyć grupę zakonników, którzy przeszli z Wrocławia do Brzegu i pokazać ich rolę w życiu tamtejszej wspólnoty dominikańskiej.

$\mathrm{Z}$ grona profesów wrocławskich rekrutowali się praktycznie wszyscy przeorowie klasztoru w Brzegu z końca XV i XVI stulecia. Ich poczet otwiera Jan Cerdonis, który w 1481 r. wstąpił do nowicjatu we Wrocławiu i po złożeniu ślubów żył w tym klasztorze przez kilkanaście lat dochodząc w 1493 r. do stanowiska podprzeora - ten sam Jan wprowadzał w latach 90. reformę obserwancką w Brzegu i jako pierwszy przeor zreformowanego w 1495 r. klasztoru zmarł w nim w następnym (1496) roku ${ }^{71}$. Jego następcą był Jerzy Carnificis z Oławy. On także był wychowankiem wrocławskiego nowicjatu, do którego wstąpił w $1480 \mathrm{r}$. W klasztorze wrocławskim przebywał przez następne dwie dekady - przyjął w nim święcenia kapłańskie i sprawował funkcje organisty (1493-1495) oraz podprzeora (przed 1498). Mając takie doświadczenia, pod koniec XV stulecia został przeniesiony do Brzegu, gdzie w 1498 widzimy go na stanowisku przeora konwentu. W przeciwieństwie do swego poprzednika nie zakończył jednak życia w Brzegu, bowiem na początku XVI w. przebywał w klasztorze poznańskim,

${ }^{67}$ Zob. Archiwum Państwowe we Wrocławiu, sygn. Rep. 57: nr 156.

${ }^{68}$ Tamże, nr 178.

${ }^{69}$ Kłoczowski, Reforma polskiej prowincji dominikańskiej, s. 202-203.

${ }^{70} \mathrm{USB}, \mathrm{nr} 1128$.

${ }^{71}$ Obituarium, fol. 154r; BUW, rkp. IV Q 191, fol. 112v, 115r i 132r; BUW, rkp. 221a: A. Regenbauer, Chronologia descriptio Conventus S. Adalberti Episcopi et Martyris Wratisaviensis, s. 84; Kaczmarek, Konwent dominikanów wrocławskich w późnym średniowieczu, s. 213, przyp. 67. 
gdzie w $1511 \mathrm{r}$. sprawował funkcję spowiednika ${ }^{72}$. Następcą Jerzego został kolejny dominikanin z Wrocławia - Mikołaj Eberhardi, natione Ruthenus, zaczął próbę w nowicjacie konwentu św. Wojciecha w 1485 r. i tam też otrzymał formację zakonną zakończoną święceniami kapłańskimi. Z Wrocławia postąpił do Opola, gdzie na początku XVI w. działał w charakterze klasztornego kaznodziei, zaś przed rokiem 1503 zjawił się w Brzegu by - wzorem swych poprzedników - objąć tam funkcję przełożonego konwentu ${ }^{73}$. Wiele lat życia spędził też we wrocławskiej wspólnocie Ambroży z Legnicy: w latach 1490-1493 pełnił nawet funkcję magistra studentów w tamtejszej szkole i przeora. On również zawitał pod koniec swojego życia do Brzegu i w roku 1508 został na krótko tamtejszym przeorem ${ }^{74}$. Brzeskim przeorem był jeszcze jeden wychowanek konwentu z Wrocławia, czyli Jan Pileatoris (Hutter). Do nowicjatu w klasztorze św. Wojciecha wstąpił w roku 1485 i przez następnych wiele lat przebywał tam jako zwykły profes ze święceniami kapłańskimi. W 1508 roku awansował jednak na przeora w Brzegu, zaś kilka lat później (1515) spisał nekrolog konwentu ${ }^{75}$.

Wrocławskie pochodzenie możemy też stwierdzić w odniesieniu do dwóch podprzeorów brzeskich z przełomu XV i XVI stulecia. Najpierw (1492 r.) widzimy na tym stanowisku brata Macieja Foyta - o jego życiu w zakonie nie zachowało się wiele danych, ale wiadomo, że przed objęciem funkcji w Brzegu przebywał w konwencie św. Wojciecha, gdzie w 1478 r. występuje jako zwykły profes ze święceniami kapłańskimi ${ }^{76}$. Po nim stanowisko brzeskiego podprzeora objął brat Kacper Braxiatoris, który swą zakonną karierę zaczynał w 1477 r. jako nowicjusz w konwencie wrocławskim, ale przed rokiem 1505 przeszedł do Brzegu i włączył się do kierowania tamtejszym konwentem, w którym zresztą zmarł ${ }^{77}$.

Poza zakonnikami z konwentu wrocławskiego, którzy objęli w konwencie Św. Krzyża najważniejsze funkcje związane z zarządzaniem klasztorem, widzimy też w tym domu spory zastęp braci z konwentu św. Wojciecha, którzy w klaszto-

${ }^{72}$ BUW, rkp. IV Q 191, fol. 112v, 113r i 132v; Regenbauer, Chronologia descriptio, s. 85; Kaczmarek, Konwent dominikanów wrocławskich w późnym średniowieczu, s. 214, przyp. 83.

${ }^{73}$ BUW, rkp. IV Q 191, fol. 112v, 113v i 114r; Regenbauer, Chronologia descriptio, s. 86; Kaczmarek, Konwent dominikanów wrocławskich w późnym średniowieczu, s. 215-216, przyp. 92.

${ }^{74}$ BUW, rkp. IV Q 191, fol. 112v, 113r, 113v i 132r; BUW, rkp. IV F 222, fol. 57; Regenbauer, Chronologia descriptio, s. 86; Eisert, Das Dominikanerkloster in Brieg (1336-1545), s. 90; Bucichowski, Lista lektorów dominikańskich prowincji polskiej, s. 79: nr 31; Kaczmarek, Szkoły i studia polskich dominikanów w okresie średniowiecza, s. 428: nr 11; Kaczmarek, Konwent dominikanów wrocławskich w późnym średniowieczu, s. 218, przyp. 112.

${ }^{75}$ BUW, rkp. IV Q 191, fol. 112v, 113v, 114r i 115r; Obituarium, fol. 157v; Regenbauer, Chronologia descriptio, s. 86; Eisert, Das Dominikanerkloster in Brieg (1336-1545), s. 90 błędnie podaje, że Jan został wybrany przeorem dopiero w roku 1514; Kaczmarek, Konwent dominikanów wrocławskich w późnym średniowieczu, s. 217, przyp. 103.

${ }^{76}$ BUW, rkp. IV Q 191, fol. 112r i 132r; Kaczmarek, Konwent dominikanów wrocławskich w późnym średniowieczu, s. 209, przyp. 30.

${ }^{77}$ BUW, rkp. IV Q 191, fol. 112r, 113v, 114r i 132v; BUW, rkp IV F 222, fol. 9; Obituarium, fol. 116r; Eisert, Das Dominikanerkloster in Brieg (1336-1545), s. 90, błędnie wyznaczył zgon zakonnika na rok 1507; Kaczmarek, Konwent dominikanów wrocławskich w późnym średniowieczu, s. 211, przyp. 49. 
rze brzeskim występują w charakterze profesów, znamy nawet - to w realiach polskiej prowincji dominikanów rzadka sytuacja - kilku braci pełniących tam funkcje konwersów. Około 1483 r. w Brzegu przebywał były infirmarz wrocławski, brat Jakub Sartoris ${ }^{78}$. Jaką funkcję sprawował w konwencie Św. Krzyża, tego nie wiemy - źródła wzmiankują go jako zwykłego kapłana, ale nie da się wykluczyć, że doświadczenia zebrane we Wrocławiu w zakresie opieki nad chorymi i starszymi braćmi zakonnik ten wykorzystywał także w konwencie brzeskim. Nieco później jako członek konwentu brzeskiego występuje w źródłach Tomasz Linificis z Budziszyna. Wiadomo, że wcześniej zakonnik ten przebywał we Wrocławiu - źródła wzmiankują jego pobyt w konwencie św. Wojciecha w latach 1478-1495 i podają, że pełnił on we Wrocławiu funkcję terminarza. W Brzegu spotykamy go w roku 1497 jako szeregowego kapłana, ale nie wykluczałbym, że praktyka w kwestowaniu i zbieraniu ofiar na potrzeby klasztoru nabyta podczas pobytu we Wrocławiu była przezeń wykorzystywana także w Brzegu ${ }^{79}$. Zakonne życie rozpoczynał w nowicjacie wrocławskim również brat Wincenty, który wstąpił do klasztoru w 1484 r. i przez następne 10 lat mieszkał w konwencie św. Wojciecha by następnie przenieść się do Brzegu, gdzie w roku 1498 przebywał jako wyświęcony kapłan w charakterze zwykłego profesa ${ }^{80}$. Podobną drogą podążył także brat Marcin Lindener, który wstąpił do wrocławskiego nowicjatu w 1488 r., przez kilka lat mieszkał w tym domu dochodząc do święceń kapłańskich, a pod sam koniec XV w. (1498 r.) przebywał w takim właśnie charakterze w Brzegu. Potem wrócił do Wrocławia, gdzie w 1531 r. zmarł jako spowiednik w miejscowym klasztorze sióstr dominikanek ${ }^{81}$. Z Wrocławia wywodził się również inny profes brzeski, brat Hieronim Hofman, który po odbyciu nowicjatu w konwencie św. Wojciecha (1479 r.) i osiągnięciu święceń kapłańskich działał w klasztorze brzeskim w $1498 \mathrm{r}^{82} \mathrm{~W}$ tym samym czasie (1498 r.) w Brzegu przebywał także brat Adam ze Świdnicy. Jego pochodzenie może być trochę mylące, gdyż Adam odbył nowicjat w klasztorze wrocławskim (1492 r.) i tam też początkowo przebywał po złożeniu ślubów. Jaką dokładnie funkcję sprawował po przejściu do konwentu Św. Krzyża - trudno powiedzieć; ponieważ jednak w początkach XVI w. w klasztorze brzeskim występuje zakrystianin, Adam Gucleber, możliwe, że postaci te da się zidentyfikowaćs ${ }^{83}$. Dalsze losy brata Adama są trudne do odtworzenia - wiemy tylko, że w 1507 r. kapituła prowincji obradująca w klasztorze sandomierskim

${ }^{78}$ BUW, rkp. IV Q 191, fol. 112r i 131v; BUW, rkp. IV F 222, fol. 33; Kaczmarek, Konwent dominikanów wrocławskich w późnym średniowieczu, s. 209, przyp. 29.

${ }^{79}$ BUW, rkp. IV Q 191, fol. 112r, 112v i 132r; BUW, rkp. IV F 222, fol. 55; Obituarium, fol. $158 \mathrm{v}$; Kaczmarek, Konwent dominikanów wrocławskich w późnym średniowieczu, s. 207, przyp. 15.

${ }^{80}$ BUW, rkp. IV Q 191, fol. 112v, 113r i 115r; Kaczmarek, Konwent dominikanów wroctawskich w późnym średniowieczu, s. 218, przyp. 109.

${ }^{81}$ BUW, rkp. IV Q 191, fol. 112v, 113r i 115v; BUW, rkp. IV F 222, fol. 2, Archiwum Państwowe we Wrocławiu, sygn. Rep 57: nr 420; Kaczmarek, Konwent dominikanów wrocławskich w późnym średniowieczu, s. 217, przyp. 102.

${ }^{82}$ BUW, rkp. IV Q 191, fol. 112v, 113r, 114v i 132v; Kaczmarek, Konwent dominikanów wroctawskich w późnym średniowieczu, s. 222, przyp. 161.

${ }^{83}$ Obituarium, fol. $142 \mathrm{v}$. 
darowała mu jakieś bliżej nieznane winy i przywróciła go do łask zakonu, zaś w roku następnym zakonnik zmart ${ }^{84}$. W 1498 r. w konwencie brzeskim odnajdujemy także brata Wawrzyńca z Kożuchowa (de Freistad), który - jak wyżej wymienieni - odbył wpierw (1490 r.) nowicjat we Wrocławiu, następnie otrzymał tam formację zakonną zwieńczoną wyższymi święceniami, a potem (jako kapłan) został przeniesiony do klasztoru Św. Krzyża. Jego pobyt w Brzegu nie trwał jednak długo, bowiem już na początku XVI w. brat Wawrzyniec zmarł jako profes w klasztorze dominikańskim w Legnicy ${ }^{85}$. Nieco inaczej potoczyły się zakonne losy brata Anioła (Andrzeja) Tabernatorisa, który co prawda także przeszedł przez nowicjat we Wrocławiu, ale (inaczej niż przywołani wcześniej zakonnicy) do Brzegu został skierowany niemal zaraz po złożeniu zakonnych ślubów - w konwencie Sw. Krzyża przebywał jako młody zakonnik wyświęcony do stopnia subdiakona tylko jeden rok (1498 r.). Zaraz potem wrócił do Wrocławia i w domu tym pozostał przez resztę życia, pełniąc w nim odpowiedzialne funkcje magistra studentów w szkole partykularnej (1514 r.) i klasztornego kaznodziei (1515 r. $)^{86}$. Z ogarniętego już duchem Reformacji Brzegu pochodzi wiadomość o dominikaninie Łukaszu, który opuścił klasztor i wziął ślub z kobietą nieznanego imienia ${ }^{87}$.

Garść informacji o zakonnikach związanych z klasztorem w Brzegu przynosi też miejscowy nekrolog zaprowadzony przez znanego nam już Jana Pileatorisa. Pod rokiem 1506 zanotowano w nim wiadomość o zgonie profesa brzeskiego, brata Walentego ${ }^{88}$. Dwa lata później do nekrologu wpisano wspomnienie o bracie Jerzym ze Zgorzelca ${ }^{89}$. Niedługo potem (1513 r.) do mortuarza wpisano informację o bracie Walentym, subdiakonie z klasztoru w Kościanie, który zginął nagłą śmiercią (crudeliter sed innocenter prope Olaviam occisus) i został pochowany w Brzegu ${ }^{90}$; nie mamy jednak pewności, czy był on członkiem tego konwentu, czy też związały go z nim dopiero tragiczne okoliczności zgonu. Z 1522 r. pochodzi informacja o zgonie brata Hermolausa z konwentu wrocławskiego, który w klasztorze brzeskim pełnił funkcję klasztornego kaznodziei ${ }^{91}$. Nekrolog trzy lata później (1536 r.) wspomina zgon brata Franciszka, kantora konwentu ${ }^{92}$.

${ }^{84}$ BUW, rkp. IV Q 191, fol. 112v, 113r, 115v i 132v; BUW, rkp. IF V 222, fol. 44; Obituarium, fol. 142v; ACPP, s. 171; Kaczmarek, Konwent dominikanów wrocławskich w późnym średniowie$c z u$, s. 219, przyp. 120.

${ }^{85}$ BUW, rkp. IV Q 191, fol. 112v, 113r, 115v i 132r; ACPP, s. 624; Kaczmarek, Konwent dominikanów wrocławskich w późnym średniowieczu, s. 217, przyp. 107.

${ }^{86}$ BUW, rkp. IV Q 191, fol. 113r, 114r, 116r i 132v; BUW IV F 222, fol. 16; ACPP, s. 208; Kaczmarek, Konwent dominikanów wrocławskich w późnym średniowieczu, s. 230-231, przyp. 290.

${ }^{87}$ USB, s. 193: nr 1394.

${ }^{88}$ Obituarium, fol. $123 \mathrm{v}$.

${ }^{89}$ Tamże, fol. $144 \mathrm{r}$.

${ }^{90}$ Tamże, fol. 113r.

${ }^{91}$ Tamże, fol. 117r.

${ }^{92}$ Tamże, fol. 117v; por. Eisert, Das Dominikanerkloster in Brieg (1336-1545), s. 93; o kasacie klasztoru brzeskiego także M. Plutarski, Brzeg w czasach rządów księcia Fryderyka II (1521-1547), w: Miasta polskie w średniowieczu i czasach nowożytnych, red. P. Gołdyn, Kraków 2008, s. 45-48. 
$\mathrm{Z}$ roku 1537 (lub 1539) pochodzi informacja o zgonie nieznanego skądinąd brata Ignacego de Mielitz $^{93}$.

W składzie osobowym konwentu brzeskiego udało się też odnaleźć kilku zakonników pełniących funkcje braci służebnych, czyli konwersów. Podkreślamy ten fakt, bowiem ta kategoria zakonników jest - generalnie rzecz biorąc - trudno uchwytna w źródłach i nie pozostawiła po sobie zbyt wielu śladów działalności. Pierwszym z brzeskich konwersów był Mikołaj Herman, który co prawda jest w aktach kapituły prowincjalnej z 1465 r. pozbawiony tego miana, ale skądinąd wiadomo, że w 1483 r. zakonnik ten zmarł w czasie wielkiej epidemii właśnie jako konwers $\mathrm{w}$ klasztorze opolskim ${ }^{94}$. Zmiana statusu zakonnika $\mathrm{z}$ konwersa na brata chórowego, choć trudna, była wykonalna ${ }^{95}$, trudno jednak sobie wyobrazić sytuację odwrotną. W tej sytuacji zakładamy, że w 1465 r. brat Mikołaj był asygnowany do klasztoru brzeskiego właśnie w charakterze brata służebnego. Nie ma takich wątpliwości w przypadku pięciu pozostałych zakonników o takim statusie: w 1498 r. w charakterze konwersów w konwencie Św. Krzyża występują: Jerzy (wcześniej - w 1495 r. - konwers we Wrocławiu) ${ }^{96}$, a także Adam Pistoris (wcześniej - w latach 1493 i 1495 - także występujący wśród konwersów w klasztorze wrocławskim $)^{97}$. Nieco później (1501 r.) jako konwers w Brzegu zmarł także brat Mikołaj Kozel, który we wcześniejszych latach (1495 r.) pełnił analogiczną funkcję w konwencie św. Wojciecha ${ }^{98}$. Pod rokiem 1509 nekrolog konwentu brzeskiego notuje zgon brata Bartłomieja, konwersa i klasztornego kucharza ${ }^{99}$. Osoba ta jest skądinąd nieznana i tylko na zasadzie hipotezy i możliwej zbieżności z losami innych brzeskich konwersów, którzy w dużej liczbie rekrutowali się z klasztoru we Wrocławiu, także Bartłomieja identyfikujemy z konwersem o takim samym imieniu, który w 1503 r. wstąpił do wrocławskiego nowicjatu ${ }^{100}$. Ostatnim ze znanych nam konwersów w klasztorze w Brzegu był wzmiankowany już wcześniej Andrzej z Ziębic, wymieniony w aktach kapituły prowincji z roku 1514, który $\mathrm{w}$ klasztorze brzeskim przebywał w charakterze terminarza aż do swej śmierci w $1535 \mathrm{r}^{101}$

${ }^{93}$ Obituarium, fol. 135 r.

${ }^{94}$ ACCP, s. 82; BUW, rkp. IV Q 191, fol. 131v; o roli konwersów w życiu klasztorów dominikańskich por. O' Daniel, The Dominican Lay Brother, New York 1921; także P.F. Mulhern, The early Dominican laybrother, Washington 1944; także K. Kaczmarek, Fratres laici-o liczbie i roli konwersów w średniowiecznej prowincji polskich dominikanów na przykładzie klasztoru we Wrocławiu, w: Duchowieństwo i laicy, red. A. Wałkówski, Warszawa 2010, s. 63-80.

${ }^{95}$ Tamże, s. 73.

${ }^{96}$ BUW, rkp. IV Q 191, fol. 113r, 114v i 132r; Kaczmarek, Konwent dominikanów wroctawskich w późnym średniowieczu, s. 226, przyp. 218.

${ }^{97}$ BUW, rkp. IV Q 191, fol. 112v, 113r i 115r; Kaczmarek, Konwent dominikanów wroctawskich w późnym średniowieczu, s. 220, przyp. 131.

${ }^{98}$ BUW, rkp. IV Q 191, fol. 113r, 114v i 132r; Kaczmarek, Konwent dominikanów wroctawskich w późnym średniowieczu, s. 230, przyp. 271.

${ }^{99}$ Obituarium, fol. 113v.

${ }^{100}$ BUWr, rkp. IV Q 191, fol. 116v.

${ }^{101}$ Obituarium, fol. $152 \mathrm{r}$. 
Podkreślony wyżej fakt rekrutowania się dużej grupy brzeskich dominikanów spośród profesów wrocławskiego konwentu św. Wojciecha, a także uchwytny $\mathrm{w}$ aktach kapituł prowincji proces asygnowania do Brzegu sporej liczby profesów z innych domów zakonnych, każe postawić pytanie o skalę rekrutacji do dominikańskiego nowicjatu na miejscu, w samym Brzegu. Nie ulega wątpliwości, że miasto miało odpowiedni potencjał ludzki, by konwent mógł prowadzić nabór chętnych do nowicjatu - według różnych szacunków w późnym średniowieczu mogło ono liczyć 2.000-3.000 mieszkańców ${ }^{102}$. O tym, że taka rekrutacja faktycznie miała miejsce, a brzescy dominikanie $\mathrm{w}$ zgodzie $\mathrm{z}$ zaleceniami kapituł generalnych prowadzili nowicjat może świadczyć podniesiony już wcześniej fakt obecności w ich klasztorze synów brzeskich patrycjuszy, a także odmiejscowe przydomki występujące przy imionach niektórych zakonników świadczące o ich pochodzeniu z okolic miasta: Jan i Paweł Mechewiczowie przebywający $\mathrm{w}$ konwencie $\mathrm{w}$ połowie XV stulecia wywodzili się zapewne z położonych opodal Brzegu Miechowic (dziś Miechowice Oławskie) ${ }^{103}$. O miejscowym pochodzeniu niektórych zakonników świadczą też dowodnie wzmianki w klasztornym nekrologu: zmarły w 1517 r. Marcin Pileatoris został tam wyraźnie określony jako civitatis et conventus huius filius nativus ${ }^{104}$. W podobny sposób opisano zmarłego w roku 1533 Dominika Rabischa, który występuje w mortuarzu jako filus nativus huius conventus Bregensis ${ }^{105}$. Trzy lata później (1536 r.) nekrolog wspomina zgon brata Walentego Rimera, także określonego w źródle jako „syn konwentu brzeskiego"106. Pośrednią, już nie tak oczywistą jak wyżej przywołane, wzmianką, która także może świadczyć o pochodzeniu niektórych dominikanów brzeskich z najbliższego otoczenia klasztoru są towarzyszące niektórym z nich przydomki „odzawodowe" lokujące ich rodziny w obrębie działających w Brzegu cechów - możliwe, że znani z dokumentu wydanego w 1458 r. Jan Sartoris oraz Ludwik Sartoris pochodzili ze środowiska brzeskich krawców, o których wiadomo skądinąd, że utrzymywali bliskie związki z klasztorem Braci Kaznodziejów ${ }^{107}$.

Mimo, że przywołane wyżej wzmianki potwierdzają oczywisty skądinąd fakt prowadzenia przez brzeskich dominikanów naboru do nowicjatu w najbliższym sąsiedztwie klasztoru, nie wydaje się by rekrutacja ta miała znaczące rozmiary. Pomijając fakt, że część mieszkańców Brzegu z pewnością nie była zainteresowana wstąpieniem do klasztoru dominikanów ${ }^{108}$, można wskazać na dwie inne okoliczności, które z pewnością wpływały na poziom rekrutacji nowicjuszy na terenie samego miasta i jego okolic. Po pierwsze, trzeba pamiętać o tym, że w Brzegu, ośrodku zamieszkiwanym u schyłku średniowiecza przez co najwyżej 3.000

${ }^{102}$ Dziewulski, Brzeg od lokacji na prawie zachodnim do wygaśnięcia dynastii Piastów (12471675), s. 94-94.

${ }^{103}$ Podobnie Eisert, Das Dominikanerkloster in Brieg (1336-1545), s. 89.

${ }^{104}$ Obituarium, fol. 130v.

${ }^{105}$ Tamże, fol. 116 r.

${ }^{106}$ Tamże, fol. 128r: „Obiit frater Valentinus Rhiemer, sacerdos, huius conventus filius nativus”.

${ }^{107}$ Kersten, Geschichte der Schneider-Innung zu Brieg, passim.

${ }^{108}$ S. Gawlik, Ludność żydowska w Brzegu od XIV w. do 1942 r., „Biuletyn Żydowskiego Instytutu Historycznego w Polsce", 1-2 (137-138), 1986, s. 19-21. 
mieszkańców, klasztor Św. Krzyża nie był jedyną mendykancką placówką zakonną. Już wcześniej, około 1280 r., w mieście pojawili się zakonnicy franciszkańscy $\mathrm{i}$ to ich klasztor (zdaje się) dzierżył prymat wśród kościelnych fundacji w Brzegu - kiedy w 1375 r. biskup wrocławski Przecław z Pogorzeli ustalał porządek procesji w mieście zarządził, że mają je otwierać właśnie minoryci, a dopiero po nich miejsce zajmowali: przeor dominikanów, komtur joannitów i pleban kościoła parafialnego ${ }^{109}$. Nie ulega więc wątpliwości, że na terenie miasta dominikanie musieli rywalizować o nowe powołania z Braćmi Mniejszymi. Po drugie, klasztor w Brzegu powstał w miejscu dosłownie otoczonym innymi, starszymi od niego, fundacjami Braci Kaznodziejów. W odległości jednego dnia drogi działały dwa inne duże konwenty dominikańskie: we Wrocławiu ${ }^{110}$ i Opolu ${ }^{111}$, a jeszcze bliżej, niemal u wrót miasta, istniał też założony około 1285 r. konwent w Lewinie Brzeskim $^{112}$. Tak wielkie zagęszczenie fundacji dominikańskich, na bardzo niewielkim przecież obszarze, nie mogło pozostawać bez wpływu na wielkość okręgów tych domów, w granicach których bracia mogli prowadzić pracę duszpasterską, kwestę, a także nabór chętnych do nowicjatu. Klasztor Św. Krzyża był nadto najmłodszą z tych placówek, musiał wiec działać w warunkach utrwalonych wcześniej wpływów i sympatii dla istniejących już, starszych od niego, konwentów. Największą konkurencją był dla niego bez wątpienia klasztor św. Wojciecha we Wrocławiu, który prowadził bardzo intensywną i szeroko zakrojoną rekrutację, która sięgała samego Brzegu - znany jest przypadek Bernardyna z Brzegu, który - choć mógł wstąpić do nowicjatu w swym rodzinnym mieście - jako miejsce swej zakonnej formacji wybrał jednak klasztor wrocławski ${ }^{113}$. Wydaje się więc, że z wymienionych powodów konwent Św. Krzyża miał ograniczone możliwości pomnażania swych ludzkich zasobów w oparciu o własny nowicjat. Być może to właśnie z tego względu tak władze prowincji, jak i położony opodal duży i zasobny w ludzi klasztor we Wrocławiu musiały go wspierać praktycznie w ciągu całej (skądinąd krótkiej) historii tego domu.

${ }^{109}$ USB, s. 52: nr 367b.

${ }^{110} \mathrm{Na}$ temat klasztoru wrocławskiego zob. wyżej, przyp. 2.

${ }^{111}$ W sprawie dominikanów opolskich zob. głównie Kłoczowski, Dominikanie polscy na Ślasku, s. 304-305; A. Pobóg-Lenartowicz, Jeszcze o początkach klasztoru dominikanów w Opolu, „Zeszyty Naukowe Uniwersytetu Opolskiego. Historia”, 35 (1998) s. 7-22.

${ }_{112}$ Zob. Kłoczowski, Dominikanie polscy na Śląsku, s. 305; także Z. Mazur, Przyczynki do historii klasztoru dominikańskiego w Lewinie Brzeskim, „Acta Universitatis Wratislaviensis No 126, Historia XIX", Wrocław 1970, s. 121-132.

${ }^{113}$ BUW, rkp. IV Q 191, fol. 115r. 


\section{BIBLIOGRAFIA}

\section{Źródła}

Archiwum Państwowe w Toruniu,

sygn. Klasztor dominikanów 23.

Archiwum Państwowe we Wrocławiu,

sygn. Rep. 57.

Archiwum Polskiej Prowincji Dominikanów w Krakowie,

sygn. Lw 11.

Biblioteka Uniwersytetu Wrocławskiego. Oddział Rękopisów

sygn. IV F 221, 221a i IV Q 191.

Acta Capitulorum Generalium Ordinis Praedicatorum, t. 2. Ab anno 1304 usque ad annum 1378, ed. B.M. Reichert, Romae 1899, s. 417 (Monumenta Ordinis Praedicatorum Historica, t. 2).

Acta Capitulorum Provinciae Poloniae Ordinis Praedicatorum, t. 1, ed. R.M. Madura, Romae 1970.

Akta grodzkie i ziemskie z czasów Rzeczypospolitej Polskiej z archiwum tak zwanego bernardyńskiego we Lwowie, t. 2, Lwów 1870.

Henricus Bitterfeld de Brega OP, Tractatus de vita contemplativa et activa, ed. B. Mazur, L. Seńko, R. Tatarzyński, Warszawa 2003.

Obituarium (Calendarium) conventus Bregensis, Biblioteka Uniwersytecka we Wrocławiu. Oddział Rękopisów, sygn. IV F 174.

Urkunden der Stadt Brieg, hrsg. von C. Grünhagen, Breslau 1870 (Codex Diplomaticus Silesiae, 9. Bd).

Zbiór formuł zakonu dominikańskiego prowincji polskiej z lat 1338-1411, wyd. J. Fijałek, „Archiwum Komisji Historycznej”, 12 (1919-1938) s. 219-428.

\section{Opracowania}

Blasel C., Geschichte von Kirche und Kloster St. Adalbert zu Breslau, Breslau 1912.

Bucichowski W., Lista lektorów dominikańskich prowincji polskiej od erygowania prowincji (1225) do roku 1525, „Przegląd Tomistyczny”, 6-7 (1997) s. 45-231.

Dola K., Dzieje Kościoła na Śląsku, cz. 1. Średniowiecze, Opole 1996.

Dziewulski W., Brzeg od lokacji na prawie zachodnim do wygaśnięcia dynastii Piastów (1247-1675), w: Brzeg. Dzieje, gospodarka, kultura, pod red. W. Dziewulskiego, Opole 1975, s. 32-142.

Eisert K., Das Dominikanerkloster in Brieg (1336-1545), „Archiv für Schlesische Kirchengeschichte", 18 (1960) s. 70-94.

Festchirift zur Feier des 250 jährigen Wiederbestehens der katholischen Gemeinde in Brieg, hrsg. von P. Hadamczik, Brieg 1927.

Festschirift zur 400 Jahr-feier der Brieger Reformation, hrsg. von W. Gunkel, Brieg 1924.

Gałuszka T., Fragment akt kapituły prowincjalnej dominikanów polskich z lat dziewięćdziesiatych XIV wieku. Studium historyczne i edycja tekstu, „Roczniki Historyczne”, 79 (2013) s. 119-145.

Gałuszka T., Fragmenty czternastowiecznych akt kapitul prowincjalnych dominikanów polskich w zbiorach Bayerische Staatsbibliothek w Monachium. Kapituła prowincjalna w Opatowcu w 1384 r., ,Studia Źródłoznawcze”, 51 (2013) s. 107-122. 
Gałuszka T., Szkolnictwo konwentualne i partykularne w strukturach polskiej prowincji dominikanów XIV stulecia. Nowe ujęcie w świetle nowych źródet, „Roczniki Historyczne", 78 (2012) s. 191-211.

Gawlik S., Ludność żydowska w Brzegu od XIV w. do 1942 r., „Biuletyn Żydowskiego Instytutu Historycznego w Polsce", 1-2 (1986) s. 19-33.

Heyne J., Dokumentirte Geschichte des Bisthums und Hochstiftes Beslau, 1. Bd, Breslau 1860 , s. $893-896$

Irgang W., Ältere Geschichte der Stadt Brieg in ihrem schlesischen Umfeld, Goslar 1988.

Kaczmarek, Fratres laici - o liczbie i roli konwersów w średniowiecznej prowincji polskich dominikanów na przykładzie klasztoru we Wrocławiu, w: Duchowieństwo i laicy, red. A. Wałkówski, Warszawa 2010, s. 63-80.

Kaczmarek K., Konwent dominikanów wrocławskich w późnym średniowieczu, Poznań-Wrocław 2008.

Kaczmarek, Szkoły i studia polskich dominikanów w okresie średniowiecza, Poznań 2005.

Kaczmarek K., Wprowadzenie, w: Metryka dominikanów poznańskich 1576-1815, wyd. K. Kaczmarek, Poznań 2016, s. V-XII.

Kersten G., Geschichte der Schneider-Innung zu Brieg, Brieg 1927.

Kielar P., Organizacja szkolnictwa dominikańskiego w XIV wieku, „Studia Philosophiae Christianane", 5 (1969) nr 1, s. 304-318.

Kielar P., Studia nad kultura szkolna i intelektualna dominikanów prowincji polskiej $w$ średniowieczu. I. Powstanie i rozwój organizacji szkolnej dominikanów w Polsce w XIII-XIV wieku, w: Studia nad historia dominikanów w Polsce 1222-1972, t. 1, pod red. J. Kłoczowskiego, Warszawa 1975, s. 271-307.

Kłoczowski J., Dominikanie polscy na Ślasku w XIII-XIV wieku, Lublin 1956.

Kłoczowski J., Jan z Brzegu, w: Polski Słownik Biograficzny, t. 10, Wrocław-Warszawa-Kraków 1962-1964, s. 443.

Kłoczowski, Polska prowincja dominikańska w średniowieczu i Rzeczypospolitej Obojga (wielu) Narodów, Poznań 2008.

Kłoczowski J., Raz jeszcze o początkach polskich dominikanów. Klasztor wrocławski wśród pierwszych konwentów prowincji polskiej, w: Błogosławiony Czesław - patron Wrocławia, t. 1. Średniowiecze i czasy nowożytne, red. M. Derwich, Wrocław-Warszawa 2006, s. 27-29.

Kłoczowski J., Reforma polskiej prowincji dominikańskiej w XV-XVI wieku, „Roczniki Humanistyczne", 4 (1953) z. 4, s. 45-92.

Kłoczowski J., Ze związków Polski z krajami zachodnimi u schyłku średniowiecza. Studia zagraniczne dominikanów prowincji polskiej, w: Polska w Europie, red. H. Zins, Lublin 1968, s. 109-136.

Koudelka V., Heinrich von Bitterfeld (+ ca 1405), Professor an der Universität Prag, „Archivum Fratrum Praedicatorum”, 23 (1953) s. 5-65.

Kubów P., Brzeg doby feudalnej w świetle badań archeologicznych przeprowadzonych w latach 1966-1976, w: Szkice brzeskie t. 1, red. D. Tomczyk, Opole 1981, s. 27-57.

Löhr G.M., Breslauer Dominikaner des 15. Jahrhundert auf auswärtigen Hochschulen, „Archiwum Fratrum Praedicatorum”, 13 (1943) s. 162-178.

Majewski J., Uwarunkowania rozwoju przestrzennego miasta Brzegu, w: Szkice brzeskie t. 1, red. D. Tomczyk, Opole 1981, s. 7-26.

Mazur Z., Powstanie i działalność inkwizycji dominikańskiej na Ślasku w XIV wieku, „Nasza Przeszłość", 39 (1973) s. 181-192.

Mazur Z., Przyczynki do historii klasztoru dominikańskiego w Lewinie Brzeskim, „Acta Universitatis Wratislaviensis” Nr 126, Historia XIX, Wrocław 1970, s. 121-132. 
Mulhern P.F., The early Dominican laybrother, Washington 1944.

Papuzińska-Mill M., Henryk Bitterfeld z Brzegu, „Przegląd Tomistyczny”, 4 (1988) s. 179190.

Plutarski M., Brzeg w czasach rząów księcia Fryderyka II (1521-1547), w: Miasta polskie w średniowieczu i czasach nowożytnych, red. P. Gołdyn, Kraków 2008, s. 43-49.

Pobóg-Lenartowicz A., Jeszcze o poczatkach klasztoru dominikanów w Opolu, „Zeszyty Naukowe Uniwersytetu Opolskiego. Historia”, 35 (1998) s. 7-22.

Schaube A., Urkundliche Geschichte der Gründung und ersten Entwickllung der deutschen Stadt Brieg. Ein Beitrag zur Kolonisationsgeschichte Schlesiens, Breslau 1934.

Schlesisches Städtebuch, hrsg. H. Stoob, P. Johanek, Stuttgart-Berlin-Köln 1995.

Schoenborn H., Geschichte der Stadt und des Fürstentums Brieg. Ein Ausschnitt aus der Geschichte Schlesiens, Brieg 1907.

Scholz F., Einführung der Reformation im Fürstentum Brieg, Brieg 1934.

Schönwälder K.F., Die Piasten zum Briege oder Geschichte der Stadt und des Fürstenthums Brieg. 1. Bd. Von den ältesten Nachrichten bis zum Jahre 1521, Brieg 1855.

Strzelecka A., Henryk z Bitterfeld, w: Polski Stownik Biograficzny, t. 9, Wrocław-Warszawa-Kraków 1960-1961, s. 420.

Szczygieł S., Początki dominikanów we Wrocławiu, w: Błogosławiony Czesław - patron Wrocławia, t. 1. Średniowiecze i czasy nowożytne, red. M. Derwich, Wrocław-Warszawa 2006, s. 31-41.

Weigel J.A.W., Geographische, naturhistorische und technologische Bechreibung des souverainen Herzogthums Schlesien, 3. Th. Die Fürstenthümer Münsterberg und Brieg, Berlin 1801.

Zajchowska A., Między uniwersytetem a zakonem. Biografia i spuścizna pisarska dominikanina Jana z Zabkowic (+1446), Warszawa 2013.

Zawadzka K., Biblioteki klasztorne dominikanów na Śląsku (1239-1810), Wrocław 1999.

Zdanek M., Fragment akt kapituly prowincjalnej dominikanów polskich z 1338 roku, „Roczniki Historyczne”, 76 (2010) s. 263-276.

Zouhar J., Dějiny a kultura slezských dominikánů v nové historiografii, „Český časopis historický", 112 (2014) nr 2, s. 287-294. 


\title{
KONWENT DOMINIKANÓW W BRZEGU W XIV-XVI WIEKU
}

\section{Streszczenie}

Historia klasztoru dominikanów w Brzegu nie cieszyła się dotąd wielkim zainteresowaniem historyków. Podstawowe do dziś opracowanie autorstwa K. Eiserta liczy kilkadziesiąt lat i jest oparte na ograniczonej podstawie źródłowej. W niniejszym opracowaniu odtworzono stan osobowy konwentu w Brzegu i jego wewnętrzną strukturę. Założony w połowie XIV w. konwent miał (jak się) wydaje dwa okresu świetności - zaraz po fundacji oraz na przełomie XV i XVI stulecia. Wiek XV natomiast, zwłaszcza jego druga połowa, to czasy mniejszego znaczenia domu w Brzegu w polskiej prowincji dominikanów. Powodem takiego stanu rzeczy był upadek klasztoru w dobie najazdów husyckich na Śląsk.

Słowa kluczowe: dominikanie; klasztor; Śląsk; Brzeg; średniowiecze; XIV-XVI w.

\section{THE DOMINICAN MONASTERY IN THE 14TH-16TH CENTURIES}

\begin{abstract}
Summary
Historians have not been much interested in the history of the Dominican monastery in Brzeg. The basic work by K. Eisert is several dozen years old and is based on a limited number of sources. The following study presents the members of the monastery in Brzeg and its internal structure. Founded in the middle of the 14th century, the monastery had - as it seems - two periods of magnificence - right after its foundation and at the turn of the 16th century. The 15 th century, especially its second half, was the time of its lesser importance. The decline of the monastery was caused by the Hussite invasions of Silesia.

Keywords: the Dominicans; a monastery; Silesia; Brzeg; the Middle Ages; 14th-16th centuries
\end{abstract}

